\title{
Islamic Education During the Covid-19 Pandemic: The Dynamic of Online Learning on Character Education
}

\author{
Mohammad Rindu Fajar Islamy \\ Universitas Pendidikan Indonesia \\ fajarislam2000@upi.edu
}

\section{Article History: Abstract:}

Submitted:

30-07-2021

Accepted:

02-09-2021

Published:

08-09-2021

This study explores the Islamic Education learning process dynamics during the Covid-19 Pandemic in the character education activities. The Covid-19 pandemic has changed the learning model from face-to-face to online learning. Developing effective and efficient online learning procedures and forms is a significant challenge faced by teachers. This research study incorporates a qualitative approach where data is collected through observation, interviews, and documentation. The object of the research were three government schools, namely SMPN 3 Lembang, SMKN 10 Bandung, and SMAN 1 Sungailiat Bangka Belitung. The research question is directed to explore the dynamics and problems that arise and the role of teachers and schools in mitigating these problems. The study results showed that most online learning uses popular applications such as Zoom, Google Meet, Google Classroom, Whatsapp Group, and Quizziz. To make online learning effective, among the efforts made by the teacher were explaining the technical activities to be carried out. Constraints that often occurred are limited internet quotas, network constraints, to inadequate computer devices. Amid the challenging situation, learning to shape students' character was still undertaken by internalizing religious values manifested in various forms of simple online religious activities.

Keywords: online learning; Islamic education; Covid-19 pandemic 


\section{Introduction}

Recently, UNESCO (The United Nations Educational, Scientific and Cultural Organization), as one of the official institutions of the United Nations (UN) that oversees education and culture, predicts a transition to changes in student characteristics due to the impact of the Covid-19 pandemic. There are some discussed impacts of Covid19 in the teaching and learning processes such as VUCA Volatility (nature, velocity, volume, and dynamics of change); Uncertainty (lack of predictability of problems and events); Complexity (problem confounders and surrounding factors); and Ambiguity (the blurring of reality and the meaning of mixed conditions) ${ }^{1}$. The Corona Virus (Covid-19) outbreak, whose appearance

${ }^{1}$ L L Hadar et al., "Rethinking Teacher Education in a VUCA World: Student Teachers' SocialEmotional Competencies during the Covid-19 Crisis," European Journal of Teacher Education 43, no. 4 (2020): 573-586,

https://doi.org/10.1080/02619768.2 020.1807513 . was first announced to the public at the end of 2019 in the city of Wuhan, China ${ }^{2}$, was able to hit various regions of the world, triggering the closure of all activities by the government up to education sector area. Reported from UNESCO data, there are at least around 1.5 billion more students who are affected by the Covid-19 pandemic, the closure of schools and universities triggers anxiety which in the emergence of complex problems in the world of education among practitioners $^{3}$

2 H Nishiura, N M Linton, and A R Akhmetzhanov, "Serial Interval of Novel Coronavirus (COVID-19) Infections," International Journal of Infectious Diseases 93 (2020): 284-286, https://doi.org/10.1016/j.ijid.2020.0 2.060 .

${ }^{3}$ E Jonge, R Kloppenburg, and $P$ Hendriks, "The Impact of the COVID-19 Pandemic on Social Work Education and Practice in the Netherlands," Social Work Education 39, no. 8 (2020): 1027-1036, https://doi.org/10.1080/02615479.2 020.1823363; V Ellis, S Steadman, and Q Mao, "Come to a Screeching Halt': Can Change in Teacher Education during the COVID-19 Pandemic Be Seen as Innovation?," European Journal of Teacher Education 43, no. 4 (2020): 559-572, https://doi.org/10.1080/02619768.2 020.1821186; R C Kalloo, B Mitchell, 
The various problems related to education in Indonesia have not yet been resolved; the presence of the Corona Disease virus has triggered the growth of new issues that have never been imagined before. One of them is the challenge of presenting an online learning process that can revise students'

and V J Kamalodeen, "Responding to the COVID-19 Pandemic in Trinidad and Tobago: Challenges and Opportunities for Teacher Education," Journal of Education for Teaching 46, no. 4 (2020): 452-462, https://doi.org/10.1080/02607476.2 020.1800407; W Kidd and J Murray, "The Covid-19 Pandemic and Its Effects on Teacher Education in England: How Teacher Educators Moved Practicum Learning Online," European Journal of Teacher Education 43, no. 4 (2020): 542-558, https://doi.org/10.1080/02619768.2 020.1820480; V Varea and G González-Calvo, “Touchless Classes and Absent Bodies: Teaching Physical Education in Times of Covid-19. Sport," Education and Society 0, no. 0 (2020): 1-15, https://doi.org/10.1080/13573322.2 020.1791814; L Wang and $\mathrm{T}$ DeLaquil, "The Isolation of Doctoral Education in the Times of COVID19: Recommendations for Building Relationships within PersonEnvironment Theory," Higher Education Research and Development 39, no. 7 (2020): 1346-1350, https://doi.org/10.1080/07294360.2 020.1823326 . character at various levels 4 . Learning from China, the government took real action by exploring and increasing the literacy of teachers towards a new online-based learning system to internalize positive character education for students 5 . In the UK, the local government has even provided teachers with "pedagogic dexterity" to adapt to changes in learning modes and students' character after the Covid-19 pandemic 6 .

However, there is a tendency for rapid responses by scholars and intellectuals to find the optimal formulation of learning models during online learning both in the field of

4 Hadar et al., "Rethinking Teacher Education in a VUCA World: Student Teachers' SocialEmotional Competencies during the Covid-19 Crisis."

${ }^{5} \mathrm{E}$ Xue, $\mathrm{J} \mathrm{Li}$, and $\mathrm{L} \mathrm{Xu}$, “Online Education Action for Defeating COVID-19 in China: An Analysis of the System, Mechanism and Mode," Educational Philosophy and Theory 0, no. 0 (2020): 1-13, https://doi.org/10.1080/00131857.2 020.1821188 .

6 Kidd and Murray, "The Covid-19 Pandemic and Its Effects on Teacher Education in England: How Teacher Educators Moved Practicum Learning Online." 
Islamic religious education and others7 . For example, a research study conducted by Chinese researcher Guang Hong and his team innovated online learning after the

7 M B Cahapay, "How Filipino Parents Home Educate Their Children with Autism during COVID-19 Period," International Journal of Developmental Disabilities 0, no. 0 (2020): 1-4, https://doi.org/10.1080/20473869.2 020.1780554; Kidd and Murray, "The Covid-19 Pandemic and Its Effects on Teacher Education in England: How Teacher Educators Moved Practicum Learning Online"; S Langlois et al., "The COVID-19 Crisis Silver Lining: Interprofessional Education to Guide Future Innovation," Journal of Interprofessional Care 34, no. 5 (2020): 587-592, https://doi.org/10.1080/13561820.2 020.1800606; J Morgan-Daniel, M Ansell, and L E Adkins, "COVID-19 Patient Education and Consumer Health Information Resources and Services," Journal of Consumer Health on the Internet 24, no. 3 (2020): 302313,

https://doi.org/10.1080/15398285.2 020.1792166; N L Primdahl et al., "It's Difficult to Help When I Am Not Sitting next to Them': How COVID-19 School Closures Interrupted Teachers' Care for Newly Arrived Migrant and Refugee Learners in Denmark," Vulnerable Children and Youth Studies 16, no. 1 (2021): 75-85, https://doi.org/10.1080/17450128.2 020.1829228 .
Covid-19 pandemic by utilizing innovative technology adapted to their education system $^{8}$. Indeed, ideally, this extraordinary disaster event requires synergy between management and the learning process. According to Lokanath Mishra, a link between the change management process and the online learning process is needed ${ }^{9}$ Even further, according to Philip Altbach, future projections of the learning process have collided with several aspects; 1) Global learning by paying attention to the internationalization of the curriculum and internationalization of teacher education, 2) Integrating internationalization to achieve sustainable

8 T Y Chang et al., "Innovation of Dental Education during COVID19 Pandemic," Journal of Dental Sciences 16, no. 1 (2021): 15-20, https://doi.org/10.1016/j.jds.2020.0 7.011 .

9 L Mishra, T Gupta, and A Shree, "Online Teaching-Learning in Higher Education during Lockdown Period of COVID-19 Pandemic," International Journal of Educational Research Open 1 (2020): 100012, https://doi.org/10.1016/j.ijedro.202 0.100012 . 
development

Stimulating

languages,

competence, and global citizenship education, and 4) Creating a more comprehensive approach in various dimensions internationalization ${ }^{10}$. Several developed countries have made rapid movements to adapt to the Covid-19 pandemic conditions, such as China, Canada, the United States, Britain, and other developed countries ${ }^{11}$.

$10 \mathrm{H}$ Wit and P G Altbach, "Internationalization in Higher Education: Global Trends and Recommendations for Its Future," Policy Reviews in Higher Education 5, no. 1 (2021): 28-46, https://doi.org/10.1080/23322969.2 020.1820898 .

11 J Clarke and C Morley, "From Crisis to Opportunity? Innovations in Australian Social Work Field Education during the COVID-19 Global Pandemic," Social Work Education 39, no. 8 (2020): 1048-1057,

https://doi.org/10.1080/02615479.2 020.1836145; L Velle et al., "Initial Teacher Education in England and the Covid-19 Pandemic: Challenges and Opportunities," Journal of Education for Teaching 46, no. 4 (2020): 596-608, https://doi.org/10.1080/02607476.2 020.1803051; W O'Brien et al., "Implications for European Physical Education Teacher Education during
In Indonesia, Islamic education plays an essential role in building the character of the nation's generation towards being intellectual and religious. Character education based on the values of Islamic teachings can at least suppress harmful and even dangerous traits such as intolerance, blind fanaticism, extremist ideology, radical actions $^{12}$. Without the

the COVID-19 Pandemic: A CrossInstitutional SWOT Analysis," European Journal of Teacher Education 43, no. 4 (2020): 503-522, https://doi.org/10.1080/02619768.2 020.1823963; E Said-Hung, R Garzón-Clemente, and B Marcano, "Ibero-American Higher Education Institutions Facing COVID-19," Journal of Human Behavior in the Social Environment 31, no. 1-4 (2021): 497511 ,

https://doi.org/10.1080/10911359.2 020.1842835; E Xue et al., "How China's Education Responses to COVID-19: A Perspective of Policy Analysis," Educational Philosophy and Theory 0, no. 0 (2020): 1-13, https://doi.org/10.1080/00131857.2 020.1793653 .

12 S Harini, "Implementasi Pendidikan Karakter Dalam Kurikulum 2013," SOSIOHUMANIORA: Jurnal Ilmiah Ilmu Sosial Dan Humaniora 4, no. 2 (2018): 47-64, https://doi.org/10.30738/sosio.v4i2 .2982; M R F Islamy, Islam and Religious Moderation: The Role of School Laboratory in Negotiating 
learning process of Islamic religious education with an effective online mode, this will cause worries and anxiety about the sharper degradation of moral morality. Imagine, in the national media, there are many cases of crimes committed by students who are still in school. Serious attention must be paid to all components of education stakeholders so that the inculcation of spiritual values through PAI can run well even though it is carried out with an online model. This research was appointed to answer several research questions, including 1) what are the strategies used by PAI teachers in carrying out effective online learning, 2)

Religious Moderation Within Theological Plurality (Al-A'raf: Jurnal Pemikiran Islam Dan Filsafat, 2021), https://doi.org/10.22515/ajpif.v18i

1.3418; D Sajadi, "Pendidikan Karakter Dalam Perspektif Islam," Tahdzib Al-Akhlaq: Jurnal Pendidikan Islam 2, no. 2 (2019): 16-34, https://doi.org/10.34005/tahdzib.v 2i2.510; U Supriadi et al., "The Role of Islamic Education Teachers in Preventing Radicalism at Madrasa Aliyah," Nazhruna: Jurnal Pendidikan Islam 4, no. 1 (2021): 74-90, https://doi.org/10.31538/nzh.v4i1. 1073. what challenges they face during the learning process, and what are the efforts they make to overcome these problems, and 3) how to create learning-rich in religious values in the PAI learning model during this pandemic.

\section{Method}

This study incorporates a qualitative approach. The qualitative approach is humanistic research and can explain the naturalistic and interpretive perspectives of human experience. According to Bogdan and Taylor" Qualitative research is one of the research procedures that produces descriptive data in speech or writing and the people's behavior being observed. Through qualitative research, researchers can identify subjects and feel what they experience in everyday life. To complement and enrich the data/information obtained through in-depth interviews, the researcher explores the data/information by conducting observations, discussions, and documentation studies. The qualitative research process is 
inductive in that the learning activities such as researcher builds mobile phones, LCD abstractions, concepts, monitors. The documentation hypotheses, and theories from used is related to the school details. In qualitative research, the role of theory is not as straightforward as in quantitative analysis because the model is inductive, namely in the sequence: (1) collecting information, asking questions, (3) building categories, (4) looking for patterns (theory), and (5) constructing a theory or comparing patterns with theories.

The research was conducted during March 2021 at SMP Negeri 3 Lembang, SMK Negeri 10 Bandung, and SMA Negeri 1 Sungailiat Bangka. Data collection techniques used by researchers were interviews, observation, and documentation. The informants in this interview were PAI teachers at SMP Negeri 3 Lembang, SMK Negeri 10 Bandung, and SMA Negeri 1 Sungailiat Bangka. The observation used by the researcher in this study was participatory observation with the type of passive participation because the researcher found the use of digital media in teaching and profile and biodata of the PAI teacher concerned. In analyzing the research data, the researcher used the Miles and Huberman model. Miles and Huberman explained four stages in data analysis activities: data collection, data reduction, data presentation, and drawing conclusions.

\section{Results}

The Use and Effectiveness of Online

\section{Applications}

Learning

Online learning cannot be separated from learning applications, the presence of the Covid-19 pandemic has increased application developers to create new model learning applications that can be used by teachers and students easily and effectively. In a search conducted by researchers, most Islamic Religious Education teachers in online learning use several already popular applications, including Zoom meeting, WhatsApp Group, Google Classroom, Google Suite, and Quizziz. According to some teachers, this application is 
very popular in the teaching and learning process because its features are so complete and very easy to learn. The online learning mode forced teachers who were previously not literate to information technology to inevitably learn how to operate the above applications, mainly the intense appeals made by the government and school principals are one of the factors that also encourage these efforts.

In the digital era, there are efforts made by PAI teachers to instill digital literacy habits for students. According to the PAI teacher at SMPN 3 Lembang, the activity created in order to create a digital literacy end is to give students additional tasks to read books and materials related to learning. The same thing was done by PAI teachers in two other schools, in one of his narratives:

"To realize a learning through digital literacy media for teachers at SMA Negeri 1 Sungailiat, every time a subject schedule such as a Zoom meeting or video call is held, the teacher tries as much as possible to motivate students to read more often like the themes that students will pass in learning in the semester that is run. For example, there is material about aqidah or faith in one semester, then there is material about nuzulul qur'an, then there is material about fiqh, morality, and Islamic history."

Furthermore, at the level of implementation, there is a separation of the use of applications in lessons. At SMAN 1 Sungailiat school, PAI learning is practically using a combination of Whatsapp Group, Video calls, Voice notes, and Zoom meetings, but for their tasks they prefer Google Classroom because it is considered more suitable. For activities such as memorizing the Koran, teachers use Zoom meetings or the like to monitor them more than students upload videos of their memorization. Slightly different is done by the teachers at SMKN 1 Bandung, where they divide the activities into several processes; 1) Google Classroom is preferred to create a question-and-answer dialogue, and the process of storing question and data banks, 2) Whatsapp Group 
aims as a means of disseminating information about learning, and 3) Zoom Meeting is chosen for the direct learning process.

In the author's observation, adopting the distribution of the online learning model developed by Liu Jiexu, the learning model practiced by most PAI teachers uses the Synchronous live class-based teaching mode model. Furthermore, the Liu Jiexu Study divides online learning into at least four; 1) Synchronous

Asynchronous by recording and broadcasting teaching mode, 3) online flipped classroom teaching mode and 4) Online tutoring-based teaching mode ${ }^{13}$. In China, She portrays online learning into the future based on three strong projections; 1) Large Scale (large size), 2) openness (openness), and socialization (socialization) ${ }^{14}$.

However, when the PAI teachers were asked about using the application, most

13 Xue, Li, and $\mathrm{Xu}$, “Online Education Action for Defeating COVID-19 in China: An Analysis of the System, Mechanism and Mode."

$14 \mathrm{Xue}, \mathrm{Li}$, and $\mathrm{Xu}$. answered that learning could run effectively. Even at SMPN 1 Lembang, it was recorded that $90 \%$ of students were able to follow it consistently, although devices and networks constrained the remaining $10 \%$. According to the author, the success of learning can be learned from the technique used by Prophet Muhammad where according to Prof. Muhammad Rawwas in his work Dirasah Tahliliyyah $\mathrm{Li}$ Syahsyiyati Ar-Rosul, adhered to the principle of Mura'at AlFuruq which means always responsive. On child psychology ${ }^{15}$. A normal situation will certainly be very different from a pandemic situation, where the psychology of students is at least affected by the hustle and bustle of suffering that is happening everywhere. A good teacher is a teacher who can provide a learning model that is in line with the wishes of the child. In addition, PAI teachers are recommended to be able to adapt to the situation and carry out a continuous process of

15 M Rawwas, Dirasah Tahliliyyah Li Syahshiyati Ar-Rasul Muhammad (Dar An-Nafais, 1988). 
motivation for students, as well as create interesting curricula that can attract students' interest in learning.

\section{Discussions}

\section{Creating Optimal Islamic Education}

Growing students' interest in Islamic education requires the creativity that a teacher must do. From the discussions and interviews conducted, the authors conclude that PAI teachers undertake several strategies to make it happen: 1) Preparation Stage, Implementation Stage, and 3) Evaluation Stage.

\section{Preparation Stage}

Activities carried out by teachers before learning starts in the evening; the teacher informs his students via Whatsapp Group will be carried out the next day, such as material information to be delivered, information on teaching methods, and assignments to read (if needed) and so on. This can be seen from one of the statements from the PAI teacher at SMPN 3 Lembang:

"Often every time learning starts or during the learning schedule, or at night before tomorrow the students will study Islamic Religious Education subjects before, I always provide information on the Whatsapp Group, which contains the technical learning how tomorrow students will do it. There is no need for notification in the Whatsapp Group because the students must already know what tasks will be done through the eduku website. However, I just want to maximize it, that's why I use Whatsapp Groups."

At this stage, the teacher's role in preparing the teaching process plays a crucial role in making the Zoom room atmosphere active. Therefore, teachers are required to prepare what materials must be prepared, what teaching methods are appropriate to use in explaining the material effectively, what kind of audio-visual media can help students absorb quickly in understanding the material presented. According to the author, this stage will really determine the realization of the ideal online learning or not. Teachers who have character must have provided special time in advance to 
think related to the process of this preparation stage.

\section{Implementation Stage}

During the teachinglearning process using the Zoom Meeting application, PAI teachers at the beginning of the process usually explain the lesson plans to be delivered, then some of the time is used to deliver the material, and the rest is used to take time for discussion sessions. The uniqueness of the author found from the process that PAI teachers at SMPN 3 Lembang channeled:

\begin{abstract}
"To maximize learning, for daily tests I use Quiziz. When I use Quiziz instead of Google Classroom the interest is more in Quiziz. Because when I conducted a small survey, what was the impression of students using Quiziz, it turned out that students liked Quiziz more in a way like playing a game or games"
\end{abstract}

No less important, the teacher maximizes the learning process with several efforts: 1) Conducting periodic attendance, 2) Advising students to be on cam during learning, 3) when the teacher teaches, the students are instructed to turn off the sound, 4) During the discussion session, the teacher encourages students to be actively involved, one of which is by luring good grades for students, 5) Making interesting learning slides, 6) Recording learning, so that post-study students can repeat it, and 7) It is recommended to prepare games or games that can using the Quizziz application.

\section{Evaluation Stage}

The evaluation process is inseparable from several efforts, including 1) Preparing homework assignments for students periodically, 2) Communicating with parents to monitor student progress during the pandemic, 3) Holding UTS and UAS, and various others. at the evaluation stage, related to the potential success of the teaching and learning process, most teachers thought that online learning assisted by interesting packaging materials could encourage students' motivation to participate actively in the learning process. At this stage the majority of PAI teachers apply the principle of Reward 
and Punishment, this is done as a form of effort in order to motivate students to bring out their best abilities in the learning process. The principle of Reward and Punishment is not only applied by today's teachers, but Rasulullah has actually demonstrated the principle saw thousands of years ago in educating his family and friends where this principle in Arabic is called Al-I'timād Alā Qāidah As-Tsawā̄b wa Al-Iqāb, a good educator will always consider the principle of Reward and Punishment in its implementation ${ }^{16}$. Rewards should be prioritized over Punishment, the form of rewards can take various forms including giving grades, giving praise in front of students, giving simple gifts, honoring students, and so on. The concept of punishment in accordance with Islamic rules, namely punishment must be made in order to apply a sense of deterrence to students so that it will not be repeated in the future.

16 Rawwas.

\section{Challenges and Problems of} Online Learning

The Covid-19 Pandemic outbreak has also forced the government, represented by the Minister of Education, to implement a new policy, namely the implementation of Distance Learning (PJJ) so that online learning automatically becomes a process that teachers and students must carry out during the pandemic period. This PJJ policy has a broad impact on hundreds of thousands of schools throughout Indonesia, where an estimated 60 million students are forced to study at home. PJJ policy decisions are at least contained in the Minister of Education and Culture Decree No. 4 of 2020 regarding the implementation of education policies during the emergency period of the spread of Covid-19.

The research study showed that the PAI teachers we interviewed at least acknowledged that online learning, although on the one hand there was a positive side, but on the other hand there were also problems that arose, including 1) Device Problems and Digital 
Literacy, 2) Charachter
Problems.

Device Problems and Digital Literacy

It is generally known that the problems faced by both teachers and students in the online learning process are inadequate devices, laptops that are not up to standard, or cellphones with low specifications, so there are obstacles to run the Zoom Meeting application. According to the author, schools located in disadvantaged zones at least experience this problem more than those in developed villages or cities. Besides the economic level of the Indonesian people, which are the majority affected by this pandemic, their main priority is of course more directed to filling basic needs first than procuring sophisticated equipment at a hefty price. To reduce these obstacles, the government must make serious efforts, especially to help finance schools where the economic level of the community is low.

In addition, another obstacle found in the field is that there are still many teachers and students who are not very familiar with the Zoom meeting application, which has so many features. Automatically this can certainly hinder the learning process, and take a little longer to teach them. Furthermore, if the network signal is not good, then the quota price is so expensive, and the use of a large quota for one Zoom lesson are also the main obstacles. We can see this from the narrative of one of the PAI teachers:

"Complaints that come from students in using digital media during learning, including that student still experience confusion in using their own accounts when learning, this is due to their lack of understanding or lagging behind in obtaining information about the procedures or stages of use, then there is also a bad signal, inadequate quota or even damaged cellphones and laptops"

\section{Character Problems}

Another challenge faced by PAI teachers is related to the inculcation of character values which will be difficult compared to the face-to-face mode. Among the bad traits that can grow in line with 
online learning are indications of increasing plagiarism practices, the practice of cheating. Dishonest nature if left unchecked will certainly have a dangerous impact. The bad habit of plagiarism has even become a serious concern given by international scientists lately. They have carried out several studies in order to find the right formula to suppress cases of such irregularities ${ }^{17}$.

17 L Gourlay and J Deane, "Loss, Responsibility, Blame? Staff Discourses of Student Plagiarism," Innovations in Education and Teaching International 49, no. 1 (2012): 19-29, https://doi.org/10.1080/14703297.2 012.647780; Michael D Barr, Singapore: A Modern History (IB Tauris \& Company Limited, 2019); Y Li, "Text-Based Plagiarism in Scientific Writing: What Chinese Supervisors Think About Copying and How to Reduce It in Students' Writing," Science and Engineering Ethics 19, no. 2 (2013): 569-583, https://doi.org/10.1007/s11948-

011-9342-7; B Petrić and N Harwood, "Task Requirements, Task Representation, and Self-Reported Citation Functions: An Exploratory Study of a Successful L2 Student's Writing," Journal of English for Academic Purposes 12, no. 2 (2013): 110-124,

https://doi.org/10.1016/j.jeap.2013. 01.002; L Shi, "Rewriting and Paraphrasing Source Texts in Second Language Writing," Journal of Second
According to David Horde, cases of plagiarism malpractice can threaten the authenticity of the educational experience, threaten the quality of education, and can threaten the effectiveness of teaching at various levels of school ${ }^{18}$. Lying behavior, plagiarism is an attitude that is not justified in Islam. According to AlQardhawi, Islamic teachings are built on the principle of things based on goodness, not evil.

Language Writing 21, no. 2 (2012): 134-148, https://doi.org/10.1016/j.jslw.2012. 03.003; N Storch, "Incorporation of Source Material: The Effect of Instruction," TESOL in Context 22, no. 1 (n.d.): $38-55$, http://search.ebscohost.com/login. asp $x$ ?authtype $=$ shib\&custid $=s 47537$ 85\&groupid $=$ knjiznica\&profile $=$ eds \%5Cnhttp://www.tesol.org.au/Pub lications/TESOL-in-Context; S C Weigle and K Parker, "Source Text Borrowing in an Integrated Reading/Writing Assessment," Journal of Second Language Writing 21, no. 2 (2012): 118-133, https://doi.org/10.1016/j.jslw.2012. 03.004 .

${ }^{18} \mathrm{~N}$ C Heckler, D R Forde, and C H Bryan, "Using Writing Assignment Designs to Mitigate Plagiarism," Teaching Sociology 41, no. 1 (2013): $94-105$, https://doi.org/10.1177/0092055X1 2461471. 
Besides plagiarism, it is challenging for teachers to educate and conduct character building directly if it is done online. In the implementation of learning using Zoom meetings, students usually do not want to activate the video camera, this of course has the potential to be misused. Students can do bad activities as long as the teacher explains on Zoom. This is as told by the teacher:

"But when online like this, if there are children who do not take lessons because there is no quota or their learning tools are damaged, because the teacher does not monitor directly, it is quite confusing to be able to trust and provide input to these students. So, there is a tendency for students to be increasingly negligent in following lessons".

According to some PAI teachers, the solutions that can be done by integrating collaboration between subject teachers, homeroom teachers, vice head of student affairs and $\mathrm{BK}$ to monitor students who are less active when online learning takes place.
Internalization of Religious Values in Online Learning

Education in Islamic teachings as exemplified by Rosulullah Saw aims to direct students to achieve the best attitudes and behavior in accordance with the values of Islamic teachings ${ }^{19}$. According to Sajadi, education in an Islamic perspective is not only limited to the transfer of knowledge but is also directed more towards the transfer of values ${ }^{20}$. It is a challenge for the education system in Indonesia to create an education system that can focus on the transfer of values which to realize this must be done continuously.

Then how do PAI teachers carry out the process in order to instill the values of religious attitudes during online learning?

From the author's observations, there are several strategies used by teachers to guide, educate their students to be closer to spiritual values:

1. Get used to praying before studying. Teachers

19 M Al-Siba'i, "Al-Sīrah AlNabawiyah Durus Wa 'Ibar," 1985.

20 Sajadi, "Pendidikan Karakter Dalam Perspektif Islam." 
are directed to invite their students before the online teaching and learning process to invite them to pray to Allah SWT. they are also directed to realize that the knowledge they get is actually a gift from Allah SWT. therefore, the teacher must be able to bring the student's intellectuals to acknowledge this fact. According to Sayyid Muhammad bin Alawi Al-Maliki in the book Abwab Al-Farj, prayer is the main weapon carried out by previous pious people to achieve the success they want ${ }^{21}$

2. Get used to praying dhuha. Students who are accustomed to carrying out the Duha prayer in various Islamic literatures get many advantages, one of which is to make it easier for them to understand science.

3. Involving Parents in Monitoring Student Activities. Their role is

${ }^{21}$ M.bin A Al-Mālikī, Abwāe AlFarj (Beirut: Dār Al-Kutub AlIlmiyyah, n.d.). very much needed because $100 \%$ of the learning is carried out at home. Parents are expected to monitor their worship activities such as fardhu prayers, tadarus, and others.

4. Show videos that contain Motivational Quotes. From the author's research, there are teachers who take the initiative to carry out this strategy, and according to him this really helps students to be wiser and be religious

5. Giving positive advice on the sidelines of online learning.

Besides being an activity, a necessary process that should not be ignored is the evaluation and monitoring process that is carried out continuously. This process requires intense and solid cooperation between teachers, students, principals, vice principals, and parents' roles to create a good, effective, and well-run controlling system.

\section{Conclusion}

Online learning has different characteristics 
compared to face-to-face learning. Even though students are faced with difficult situations, they still grow into students who have good character and have sufficient intellect. This would certainly impact the various strategies used by teachers to create a teaching and learning process that runs effectively and efficiently. Teachers in schools face various problems, but teachers are required to innovate to solve the issues. Strengthening character in the online process must be undertaken by internalizing Islamic teaching values through online learning activities.

\section{References}

Al-Mālikī, M.bin A. Abwāb AlFarj. Beirut: Dār AlKutub Al-Ilmiyyah, n.d.

Al-Siba'i, M. "Al-Sīrah AlNabawiyah Durus Wa 'Ibar," 1985.

Barr, Michael D. Singapore: A Modern History. IB Tauris \& Company Limited, 2019.

Cahapay, M B. "How Filipino Parents Home Educate Their Children with Autism during COVID19 Period." International Journal of Developmental
Disabilities 0, no. 0 (2020): 1-4.

https:/ / doi.org/10.1080 /20473869.2020.1780554.

Chang, T Y, G Hong, C Paganelli, $\quad P$ Phantumvanit, W J Chang, Y S Shieh, and M L Hsu. "Innovation of Dental Education during COVID-19 Pandemic." Journal of Dental Sciences 16, no. 1 (2021): 15-20. https:// doi.org/10.1016 /j.jds.2020.07.011.

Clarke, J, and C Morley. "From Crisis to Opportunity? Innovations in Australian Social Work Field Education during the COVID-19 Global Pandemic." Social Work Education 39, no. 8 (2020): 1048-1057.

https:// doi.org/10.1080 /02615479.2020.1836145.

Ellis, V, S Steadman, and Q Mao. "Come to a Screeching Halt': Can Change in Teacher Education during the COVID-19 Pandemic Be Seen as Innovation?" European Journal of Teacher Education 43, no. 4 (2020): 559-572. https:// doi.org/10.1080 /02619768.2020.1821186. Gourlay, L, and J Deane. "Loss, Responsibility, Blame? Staff Discourses of Student Plagiarism." Innovations in Education 
and Teaching International 49, no. 1 (2012): 19-29. https:// doi.org/10.1080 /14703297.2012.647780.

Hadar, L L, O Ergas, B Alpert, and $\mathrm{T}$ Ariav. "Rethinking Teacher Education in a VUCA World:

Teachers' Student Emotional Competencies during the Covid-19 Crisis." European Journal of Teacher Education 43, no. 4 (2020): 573-586. https://doi.org/10.1080 /02619768.2020.1807513.

Harini, S. "Implementasi Pendidikan Karakter Dalam Kurikulum 2013." SOSIOHUMANIORA: Jurnal Ilmiah Ilmu Sosial Dan Humaniora 4, no. 2 (2018): 47-64. https:// doi.org/10.3073 8/ sosio.v4i2.2982.

Heckler, N C, D R Forde, and $\mathrm{C} \mathrm{H}$ Bryan. "Using Writing Assignment Designs to Mitigate Plagiarism." Teaching Sociology 41, no. 1 (2013): 94-105.

https:// doi.org/10.1177 /0092055X12461471.

Islamy, $\mathrm{M} \mathrm{R} \mathrm{F}$. Islam and Religious Moderation: The Role of School Laboratory in Negotiating Religious Moderation Within Theological Plurality. AlA'raf: Jurnal Pemikiran Islam Dan Filsafat, 2021. https://doi.org/10.2251 5/ajpif.v18i1.3418.

Jonge, E, R Kloppenburg, and P Hendriks. "The Impact of the COVID-19 Pandemic on Social Work Education and Practice in the Netherlands." Social Work Education 39, no. 8 (2020): 1027-1036. https:// doi.org/10.1080 /02615479.2020.1823363.

Kalloo, R C, B Mitchell, and V $\mathrm{J}$ Kamalodeen. "Responding to the COVID-19 Pandemic in Trinidad and Tobago: Challenges and Opportunities for Teacher Education." Journal of Education for Teaching 46, no. 4 (2020): 452-462.

https:// doi.org/10.1080 /02607476.2020.1800407.

Kidd, W, and J Murray. "The Covid-19 Pandemic and Its Effects on Teacher Education in England: How Teacher Educators Moved Practicum Learning Online." European Journal of Teacher Education 43, no. 4 (2020): 542-558. https://doi.org/10.1080 /02619768.2020.1820480.

Langlois, S, A Xyrichis, B J Daulton, J Gilbert, K Lackie, D Lising, K MacMillan, G Najjar, A L Pfeifle, and $\mathrm{H}$ Khalili. "The COVID-19 Crisis Silver Lining: 
Interprofessional

Education to Guide Future Innovation." Journal of Interprofessional Care 34, no. 5 (2020): 587592.

https:// doi.org/10.1080 /13561820.2020.1800606.

Li, Y. “Text-Based Plagiarism in Scientific Writing: What Chinese Supervisors Think About Copying and How to Reduce It in Students' Writing." Science and Engineering Ethics 19, no. 2 (2013): 569-583. https:// doi.org/10.1007 /s11948-011-9342-7.

Mishra, L, T Gupta, and A Shree. "Online TeachingLearning in Higher Education during Lockdown Period of COVID-19 Pandemic." International Journal of Educational Research Open 1 (2020): 100012. https:// doi.org/10.1016 /j.ijedro.2020.100012.

Morgan-Daniel, J, M Ansell, and $\mathrm{L} E$ Adkins. "COVID-19 Patient Education and Consumer Health Information Resources and Services." Journal of Consumer Health on the Internet 24, no. 3 (2020): 302-313. https:// doi.org/10.1080 /15398285.2020.1792166.

Nishiura, H, N M Linton, and A $\mathrm{R}$ Akhmetzhanov.
"Serial Interval of Novel Coronavirus (COVID-19) Infections." International Journal of Infectious Diseases 93 (2020): 284286.

https:// doi.org/10.1016 /j.ijid.2020.02.060.

O'Brien, W, M Adamakis, O.' Brien, Onofre N., Martins M., Dania J., Makopoulou A., et al. "Implications for European Physical Education Teacher Education during the COVID-19 Pandemic: A Cross-Institutional SWOT Analysis." European Journal of Teacher Education 43, no. 4 (2020): 503-522. https:// doi.org/10.1080 /02619768.2020.1823963.

Petrić, B, and N Harwood. “Task Requirements, Task Representation, and Self-Reported Citation Functions: An Exploratory Study of a Successful L2 Student's Writing." Journal of English for Academic Purposes 12, no. 2 (2013): 110-124.

https:// doi.org/10.1016 /j.jeap.2013.01.002.

Primdahl, N L, A S Borsch, A Verelst, S S Jervelund, I Derluyn, and M Skovdal. "It's Difficult to Help When I Am Not Sitting next to Them': How COVID-19 School 
Closures Interrupted

Teachers' Care for

Newly Arrived Migrant and Refugee Learners in Denmark." Vulnerable Children and Youth Studies 16, no. 1 (2021): 75-85.

https:// doi.org/10.1080 /17450128.2020.1829228.

Rawwas, M. Dirasah Tahliliyyah Li Syahshiyati Ar-Rasul Muhammad. Dar An-Nafais, 1988.

Said-Hung, E, R GarzónClemente, and $\mathrm{B}$ Marcano. "IberoAmerican Higher Education Institutions Facing COVID-19." Journal of Human Behavior in the Social Environment 31, no. 1-4 (2021): 497511.

https:// doi.org/10.1080 /10911359.2020.1842835.

Sajadi, D. "Pendidikan Karakter Dalam Perspektif Islam." Tahdzib Al-Akhlaq: Jurnal Pendidikan Islam 2, no. 2 (2019): 16-34. https:// doi.org/10.3400 5/tahdzib.v2i2.510.

Shi, L. "Rewriting and Paraphrasing Source Texts in Second Language Writing." Journal of Second Language Writing 21, no. 2 (2012): 134-148. https:// doi.org/10.1016 /j.jslw.2012.03.003.

Storch, N. "Incorporation of
Source Material: The Effect of Instruction." TESOL in Context 22, no. 1 (n.d.): 38-55. http://search.ebscohost. com/login.aspx?authtyp $\mathrm{e}=$ shib\&custid $=\mathrm{s} 4753785$ \&groupid=knjiznica\&pr ofile=eds $\% 5$ Cnhttp://w ww.tesol.org.au/Publica tions/TESOL-in-Context. Supriadi, U, U Romli, M R F Islamy, M Parhan, and N Budiyanti. "The Role of Islamic Education Teachers in Preventing Radicalism at Madrasa Aliyah." Nazhruna: Jurnal Pendidikan Islam 4, no. 1 (2021): 74-90. https://doi.org/10.3153 8/nzh.v4i1.1073.

Varea, V, and G GonzálezCalvo. "Touchless Classes and Absent Bodies: Teaching Physical Education in Times of Covid-19. Sport." Education and Society 0, no. 0 (2020): 115.

https:// doi.org/10.1080 /13573322.2020.1791814.

Velle, L, S Newman, C Montgomery, and D Hyatt. "Initial Teacher Education in England and the Covid-19 Pandemic: Challenges and Opportunities." Journal of Education for Teaching 46, no. 4 (2020): 596-608.

https:// doi.org/10.1080 
/02607476.2020.1803051.

Wang, L, and T DeLaquil. "The Isolation of Doctoral Education in the Times of COVID-19: Recommendations for Building Relationships within PersonEnvironment Theory." Higher Education Research and Development 39, no. 7 (2020): 1346-1350. https:// doi.org/10.1080 /07294360.2020.1823326.

Weigle, S C, and K Parker. "Source Text Borrowing in an Integrated Reading/Writing

Assessment." Journal of Second Language Writing 21, no. 2 (2012): 118-133. https:// doi.org/10.1016 /j.jslw.2012.03.004.

Wit, $\mathrm{H}$, and $\mathrm{P}$ G Altbach. "Internationalization in Higher Education: Global Trends and Recommendations for Its Future." Policy Reviews in Higher Education 5, no. 1 (2021): 28-46. https:// doi.org/10.1080 /23322969.2020.1820898.

Xue, E, J Li, T Li, and $\mathrm{W}$ Shang. "How China's Education Responses to COVID-19:

Perspective of Policy Analysis." Educational Philosophy and Theory 0, no. 0 (2020): 1-13. https:// doi.org/10.1080 /00131857.2020.1793653.
"Online Education Action for Defeating COVID-19 in China: An Analysis of the System, Mechanism and Mode." Educational Philosophy and Theory 0, no. 0 (2020): 1-13.

https://doi.org/10.1080 /00131857.2020.1821188. 
Mohammad Rindu Fajar Islamy

108 | Nadwa: Jurnal Pendidikan Islam 